\title{
Liderlik Kavramının Mükemmellik Modeline Göre İncelenmesi: Karabük Devlet Hastanesi Örneği \\ (Investigation of the Leadership Concept to Excellence Model: Karabuk State Hospital Example)
}

\section{Nurullah SOYHAN iD a Nurettin SOYHAN ${ }^{\text {iD }}$ b \\ a Karabük Üniversitesi Tıp Fakültesi, Karabük, Türkiye. nurullahsoyhan@karabuk.edu.tr \\ b Ovacık Toplum Sağlı̆̆ı Merkezi Başkanı, Karabük, Türkiye. nurettinsoyhan@hotmail.com}

\begin{tabular}{l}
\hline MAKALE BİLGİSI \\
\hline Anahtar Kelimeler: \\
Liderlik \\
Mükemmellik Modeli \\
Yapısal Eşitlik Analizi \\
Gönderilme Tarihi 29 Temmuz \\
2019 \\
Revizyon Tarihi 20 Kasım 2019 \\
Kabul Tarihi 6 Aralık 2019
\end{tabular}

\section{Makale Kategorisi: \\ Araştırma Makalesi} ÖZET

Amaç - Bu araştırmanın amacı, liderlik kavramının EFQM alt boyutları arasındaki bağı bulmak ve hangi boyutun liderlik için önemli olduğunu ortaya çıkarmaktadır.

Yöntem - Yapı düzeyi, olgunluk veya sektör seviyelerinden farklı olarak yönetim bilimleri, her kurumun başarıya ulaşabilmesi ve kendi yapısına uygun yönetim sistemini oluşturma nedenlerini gözle görülür bir şekilde ortaya koymaktadır. Bu nedenlere sonuçlar bulmak amacıyla da farklı öneri ve yaklaşımların iyileştirilmesine katkı sağlamaktadır. Bu sistemler, farklı boyutları olan yönetimin bir kısmı ile ilgilenmekte ve bu kısımlara yapılmasını uygun gördüğü özel standartlarla boyutun çerçevesini oluşturmaktadır. Lakin çok boyutlara sahip olan yönetim, işin kendisine ve işe yapan kurumlar veya işletmelere göre farklılık göstermektedir. Dolayısıyla her ölçeğin içinde bulunan ve aynı zamanda farklı sektördeki işletme ve kuruluşların yönetim bakış açılarını sorgulayabilmeleri için kolayca uygulanabilir bir araca ihtiyaç duyulmaktadır. Tam da bu durumda, bu ihtiyaca cevap verecek EFQM Mükemmellik Modeli kolay bir araç olarak ortaya çıkmaktadır. EFQM bu bağlamda liderlik kavramı içinde araştırılması gereken ve alt boyutlarının liderlik ile çağırışım yapması önemlidir. Araştırma Karabük Devlet Hastanesinde çalışan 267 kişiye anket yöntemiyle uygulanmıştır. 158 kişinin anketi yapısal eşitlik analizi ile yorumlanmıştır.

Bulgular - Elde edilen bulgulara göre boyutlar arasındaki tüm ikili korelasyon katsayıları istatistiksel olarak anlaml, pozitif yönlü ve yüksek düzeyde bulunmuştur. En yüksek korelasyon katsayısı boyut c ile boyut $\mathrm{d}$ arasında $(0,994)$, en düşük korelasyon katsayısı boyut a ile boyut $\mathrm{e}$ arasında $(0,831)$ hesaplanmıştır. Bu sonuçlara göre liderlik boyutlarından herhangi birisinde gerçekleştirilecek olan algı iyileştirmesi diğer boyutlara da pozitif yönlü ve yüksek oranda algı iyileşmesi olarak yansıyacağı şeklinde yorum yapılabilir.

Tartıșma - Kurumun yönetim sisteminin geliștirilmesi ve sürekli olarak iyileştirilmesi boyut incelendiğinde ise a boyutuna benzer sonuç çıktığını söylenebilir. " Yönetim çalışanlarla açık ve dürüst iletişimi yaklaşımı uygulamaktadır." İfadesinin boyut içinde liderlik üzerinde en büyük etkiye sahip olduğunu görülmektedir. Kurumun yönetim sisteminin geliştirilmesi ve sürekli olarak iyileştirilmesi boyutunda kurumun yönetim sisteminin geliştirilmesi ve sürekli olarak iyileştirilmesi boyutu incelendiğinde ise a boyutuna benzer sonuç çıtığını söylenebilir. "Yönetim çalışanlarla açık ve dürüst iletişimi yaklaşımı uygulamaktadır." İfadesinin boyut içinde liderlik üzerinde en büyük etkiye sahip olduğunu görmekteyiz. Paydaşlarla etkileşime girme boyutuna bakıldığında " Yönetim, yapıcı eleștiriye açıtır." ve "Yönetim, tedarikçileri uzun dönem ortağı olarak ele almaktadır." İfadeleri diğer ifadelere göre daha düşük etkilere sahip olmakla beraber "Karar alırken bu kararların içsel ve dışsal etkilerini ve yansımalarını dikkate almaktadır." ifadesi bu boyutun en yüksek etkiye sahip ifadesi olarak belirlenmiştir. Personelin mükemmellik kültürünü geliştirme boyutu incelendiğinde ifadelerin etkileri hemen hemen aynı seviyede olduğu görülmüştür. " Yönetim, hedeflere ulaşma konusunda çalışanları desteklemektedir." İfadesi boyutun en yüksek etkiye sahip ifadesi olarak söylenebilir. Personelin mükemmellik kültürünü geliştirme boyutu incelendiğinde ifadelerin etkileri hemen hemen aynı seviyede olduğu görülmüştür. " Yönetim, hedeflere ulaşma konusunda çalışanları desteklemektedir." İfadesi boyutun en yüksek etkiye sahip ifade olduğu görülmüştür. Örgütsel değişimi tanımlama ve öncülük etme boyutunda da diğer boyutlara benzer olarak birbirine yakın etkilerde bulunan ifadeler yer almaktadır. " Örgütte değişimi tetikleyen içsel ve dışsal faktörleri doğru algılamaktadır." İfadesi boyutun en yüksek etkiye sahip ifade olarak görülmektedir.

\section{Önerilen Atıf/Suggested Citation}

Soyhan., N., Soyhan., N. (2019) Liderlik Kavramının Mükemmellik Modeline Göre İncelenmesi: Karabük Devlet Hastanesi Örneği, İşletme Araştırmaları Dergisi, 11 (4), 3323-3336. 


\begin{tabular}{|c|c|}
\hline ARTICLE INFO & ABSTRACT \\
\hline $\begin{array}{l}\text { Received } 29 \text { July } 2019 \\
\text { Revised } 20 \text { November } 2019 \\
\text { Accepted } 6 \text { December } 2019\end{array}$ & 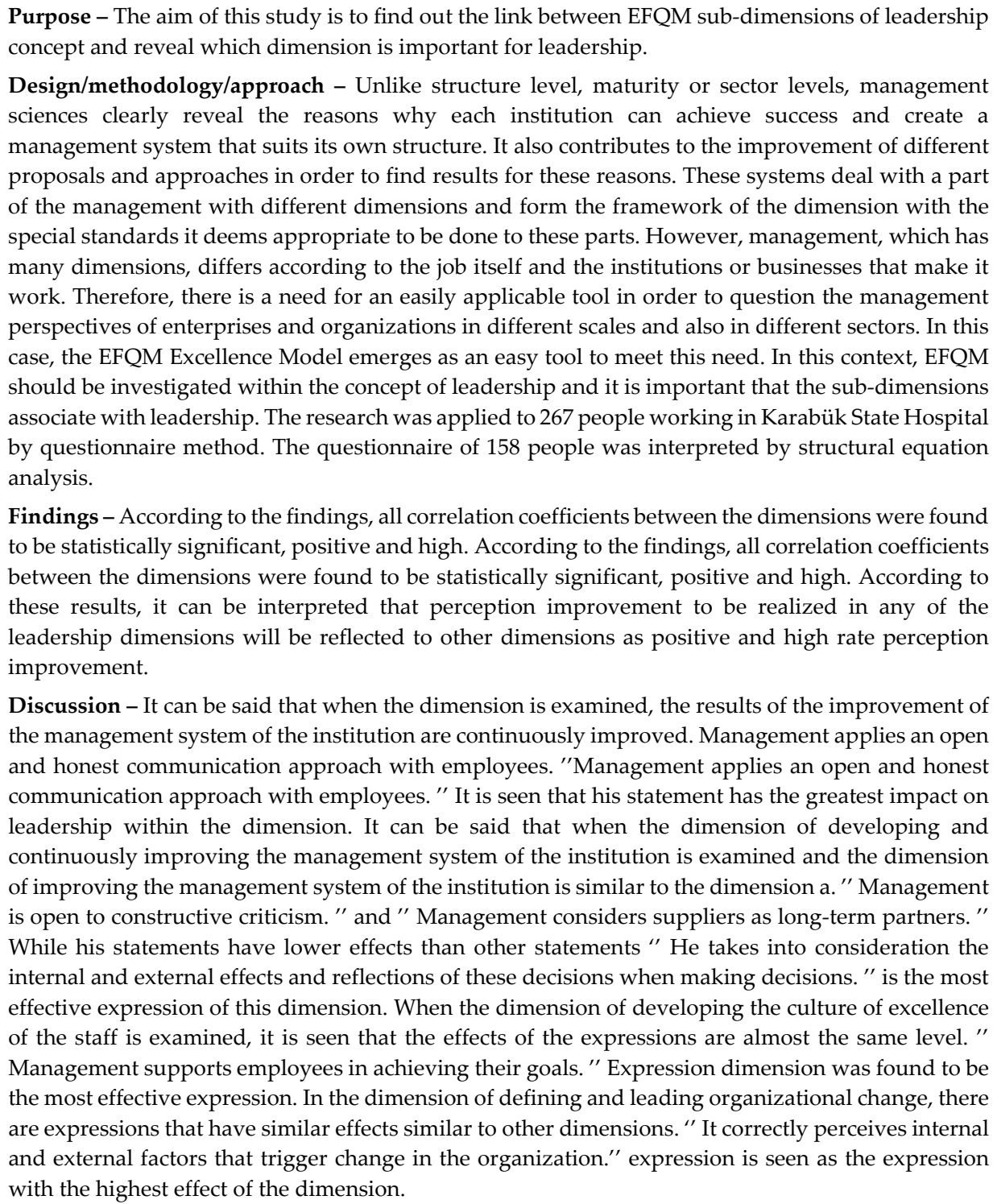 \\
\hline
\end{tabular}

\section{GİRIŞ}

Yapı düzeyi, olgunluk veya sektör seviyelerinden farklı olarak yönetim bilimleri, her kurumun başarıya ulaşabilmesi ve kendi yapısına uygun yönetim sistemini oluşturma nedenlerini gözle görülür bir şekilde ortaya koymaktadır. Bu nedenlere sonuçlar bulmak amacıyla da farklı öneri ve yaklaşımların iyileştirilmesine katkı sağlamaktadır. Bu sistemler, farklı boyutları olan yönetimin bir kısmı ile ilgilenmekte ve bu kısımlara yapılmasını uygun gördüğü özel standartlarla boyutun çerçevesini oluşturmaktadır. Lakin çok boyutlara sahip olan yönetim, işin kendisine ve işe yapan kurumlar veya işletmelere göre farklılık göstermektedir. Dolayısıyla her ölçeğin içinde bulunan ve aynı zamanda farklı sektördeki işletme ve kuruluşların yönetim bakış açılarını sorgulayabilmeleri için kolayca uygulanabilir bir araca ihtiyaç duyulmaktadır. Tam da bu durumda, bu ihtiyaca cevap verecek EFQM Mükemmellik Modeli kolay bir araç olarak ortaya çımaktadır.

EFQM (Avrupa Kalite Yönetimi Vakfı) büyüklük, yapı, sektör, ya da gelişmişlik seviyesinden özerk olarak kuruluşların sürdürülebilir mükemmelliğe ulaşmalarını desteklemek adına bir yönetim sistemi kurmaları nedenini öne çıkarmaktadır. Mükemmellik modeli (EFQM) sürekli mükemmelliği yakalamanın pek çok değişik yaklaşımı kullanarak da mümkün olabileceğini kabul eden ve reçete sunmayan bir çerçevedir. EFQM Mükemmellik Modeli, kuruluşların mükemmellik yolunda ilerleyip ilerlemediklerini ölçerek yönetim sistemlerini geliştirmeleri konusunda onlara yardımcı olan pratik bir araç niteliği taşır; kuruluşların kuvvetli yönlerini ve iyileştirmeye açık alanlarını görmelerini sağlayarak onları çözümler üretmeleri konusunda teşvik eder. Mükemmellik Modelinin temelinde Toplam Kalite Yönetimi'nin kriterleri bulunmaktadır. Model kalite 
yönetimim vasıtasıyla organizasyonların nasıl değişeceğini göstererek yönetime katkıda bulunmak amacıyla kurulmuştur. Toplam kalitenin perspektifini genişleten model, kuruluşların aşamalarına yardımcı olarak tarafsız davranış geliştirmelerini sağlamaktadır. EFQM modeli, Avrupa'da en çok başvurulan model konumundadır. Müşteri ve çalışan memnuniyetinin yanı sıra sosyal etkileri ile beraber meydana getirdiği mükemmel iş sonuçları modelin ön planda tutulan teması oluşturmaktadır.

Liderlik kavramına tarihin en eski çağlarından bu yana yönetim işlevinin olduğu her alanda çok farklı anlamlar yüklenmiş olsa da hep var olagelmiş ve önemini korumuştur. Fransızca "leader" kelimesinden gelmekte olan lider kavramı Türk Dil Kurumunda karşılığını "Önder, Şef" kelimelerinde bulmaktadır. Araştırmacılar, liderliğin tanımını daha çok kişisel perspektiflerine ve önem verdikleri olgulara göre yapmışlardır. Ancak farklı tanımlar olmasına rağmen birleştikleri ortak noktalar genelde aynıdır. Ortak payda durumundaki kriterler; belli bir amacın olması, belli bir grup insanın olması ve bu grubu yönlendirebilecek bir liderin bulunmasıdır. Bu araştırma kapsamında Karabük Devlet Hastanesi'nde çalışan 267 personelin EFQM kriterlerine dayanarak hayallerindeki liderin nasıl olması gerektiği araştırılmış, 158 kişi ankete cevap vermiş EFQM kavramının alt boyutları ve liderlik arasındaki ilişkiyi belirlemek için yapısal eşitlik analizi AMOS programı kullanılarak yapılmıştır.

\section{LIDERLIKK KAVRAMI}

Tarih hep liderlerle anılmıştır. Tarihteki büyük dönüşümleri büyük liderler gerçekleştirmişler ve bu liderler toplumlarıyla özdeşleştirilerek yıllar boyunca anlatılmıştır. İstanbul'un fethi hep Fatih Sultan Mehmet ile anılmış, Büyük İskender'in adı Makedonya' dan çok daha fazla hatırlanmıştır.

Liderlikle ilgili bilimsel araştırmalar ise 20. yüzyılın başlarında yapılmaya başlanmıştır. Bazı insanlar lider olarak öne çıkarken, başkaları neden çıkamamış sorusunun cevabı hep araştırıla gelmiştir. Bu sorunun cevabını bulabilmek için farklı liderlik tanımları ve özellikleri ortaya konulmaya çalışılmıştır.

İngilizce kökenli olan liderlik (leadership) kelimesinin fiil hali 'lead'; yön göstermek, yol göstermek, kılavuzluk etmek, öncülük etmek, rehberlik yapmak anlamına gelmektedir. "Leader" ise; rehber, kılavuz, önder, baş, lider anlamlarını taşımaktadır (Eraslan, 2004: 2).

Liderlik literatüründe önde gelen araştırmacılardan olan Burns'e (1978: 425) göre; insanların ekonomik, siyasal vb. güç ve değerleri kullanmak suretiyle bağımsız ya da ortak şekilde belirledikleri amaçları gerçekleştirmek üzere takipçilerini harekete geçmeye teşvik etmeleri süreci liderliktir. Liderlik ile ilgili literatüre önemli katkıları bulunan bir diğer araştırmacı olan Bass ise liderliği; grup üzerine odaklanma süreci, kişisel bir özellik, insanlar arasında uyumu gerçekleştirebilen bir ikna sanatı, başkalarını etkileme çabası, güç ilişkisi, amaca ulaştıran bir araç, bir yapının başlangıcı gibi birbirinden farklı şekillerde ele almıştır (Shrivastava ve Nachman, 1989: 52).

Liderin birden çok tanmı mevcuttur. Bir tanıma göre lider, insanları bir amaç doğrultusunda toplayan, sahip olduğu iç motivasyon ve kişisel özellikleri nedeniyle insanlar üzerinde etki sahibi olan kişidir. (Dinçer ve Bitirim, 2007: 61) Başka bir tanıma göre lider; yol gösteren, aydınlatan, öğreten, bireylerin ihtiyaç ve isteklerini göz önünde bulunduran sahip olduğu imaj oluşturma yeteneğiyle kişilerin düşüncelerini önemli ölçüde değiştirebilen ve etkileyebilen bir kişidir (Akman vd., 2015:131).

\subsection{LIDDERIN ÖZELLIKKLERI VE ETKINNLİKLERI}

Liderlik ile yapılan tanımların ortak notaları ve liderlik ile ilgili diğer özellikleri aşă̆ıdaki gibi belirtebiliriz. (Drucker, 2000:130)

- Mükemmel rol model olma

- Mutlak bütünlük gösterme

- Yüksek beklentilere sahip olma

- Misyonları doğrultusunda açık bir vizyona sahip olma

- Öncelikleri belirleyebilme

- Pozitif olabilme ve

- Yenilikçi olabilme

- Kişisel özelliklere bağlı olarak sahip olunan bir güç

- Karar verme ve verilen kararları uygulayabilme gücü 
- Gruba yön verme ve grup içinde eşgüdüm sağlama,

- Ortak amaçlar doğrultusunda grubu etkileme,

- Grupla birey arasında gerçekleşen etkileşim süreci

- Mevcut amaç, yapı ve prosedür ve kuralları değiştirtebilme yeteneği

- Gönüllülük temelinde çalışanların güdülenmesi, cesaretlenmesi, yönlendirilmesi

- Personelini tanıma, onların yaratıcılığını ortaya çıarma

- İnsanları anlama

- Kararlı olma olarak ifade edilmiştir.

Birçok etkin lider şu üç alanda etkinlik kümesine sahiptir (Vries, 2007:207):

- Kişisel yetkinlikler: kazanım motivasyonu, özgüven, enerji ve kişisel etkinlik gibi

- Sosyal etkinlikler: etki, politik, farkındalık ve empati gibi

- Bilişsel etkinlikler: kavramsal düşünme ve kuşbakışı gibi.

Liderlik işlevliği için kritik olan, kişilik özellikleriyle de ilişkili bazı işlevselliklerini ise şu şekilde sıralayabiliriz (Vries, 2007: 208-210):

- Kendini kabul ettirebilme; enerjik insanlardır. İşleri başarmaktan keyf alan insanlardır. Bu kişiler kendilerinden emin oldukları için, insanları yönlendirme konusunda beceriklidirler.

- Sosyallik; sosyal yetenekleri onların sürekli insanların içerisinde bulunmasını sağlar.

- Kavrayışlılık; yeni deneyimlere ve farklı fikirlere açık olan bakış açısı geniş olan insanlardır.

- Uzlaşabilirlik; esnek, işbirlikçi ve hoşlanılan dışadönük insanlardır. Kendine duyduğu güvenden ötürü insanlara güven duyarlar, kriz durumunu fırsata çevirebilirler. Onları harika takım oyuncusu yapan ise bu özelliktir.

- Güvenilirlik; vicdanı olan kişilerdir. Kendilerinden bir şey istenildiğinde bunu yapar ve sorumluluğu kendilerinde hissederler. Bu yüzden güvenilir kişilerdir ve sorumluluk sahibidirler.

- Analitik zekâ; bu yetenek sayesinde stratejik düşünüp aynı şekilde stratejik davranabilirler. Fakat bazı durumlarda yüksek zekâ seviyesi kişiyi kendi bakış açısına akılcılaştırmaya ve aşırı abartmaya teşvik edebilir.

- Duygusal zekâ; Empati kurmayı bilirler. Başkalarının ne hissettikleri hakkında bilgi sahibidirler. Bu özellikler onları diğer insanlardan ayırır. Güçlü ve zayıf yanlarının farkında oldukları için gerçeklik duygusuna sahiptirler. İlişkilerini ne şekilde yönetilmesi gerektiğinin farkındadırlar. Duygusal durumdan iradeli insanlardır.

\section{MÜKEMMELLIKK MODELİ (EFQM)}

Son yıllarda kaliteye ilişkin çok şey söylenmiş ve yazılmıştır. Bahsi geçen konu, bir üretim sisteminde küçük bir teknik araç olmanın basit kavramından, mevcut konumlandırmanın beklenmedik seviyesine ulaşmak için geliştirilmiştir (Saavedra, 2005: 7).

Bazıları kaliteyi bir ürün ya da hizmetin üstünlüğü veya mükemmelliği olarak düşünürken, bazıları da bunu imalat ya da hizmet kusurları olarak görmekteydi. Başkaları ise kalitenin ürün özellikleri veya fiyat ile ilgili olduğunu düşünmekteydi (Evans, 2008: 6).

"Mükemmeliyet" kelimesi artık iş dilinin bir parçası- ve hatta kamu sektörlerinde kâr amacı gütmemektedir. Birçok iddia şüphesiz haklı olsa da, ürünleri veya hizmetleri hakkında herhangi bir iddiada bulunan herkesin bunu kullanması gerekmektedir (Medhurst ve Richards,

2003).

Bir kurumun kapasitesi ve müşteri için önemli olan tedarik zinciri kalitesinin ve mükemmeliyetinin tüm boyutları mükemmel olma kapasitesi üzerine kurulmuştur. Türk Dil Kurumu "mükemmellik" kelimesinin anlamını-eksiksiz, kusursuz, tam, yetkin olma, mükemmeliyet-olarak tanımlamıştır (TDK). EFQM, organizasyonel bağlamda mükemmelliği ortaya koymakta ve "Organizasyonel Mükemmellik" ününü: "bir organizasyon olarak uzun vadeli başarı olasılığını arttırmak için dengeli bir paydaş memnuniyeti ile sonuçlanan çalışmaların genel yolu" olarak tanımlamaktadır (Saada, 2013: 30).

EFQM (Avrupa Kalite Yönetimi Vakfı) “1988 yılında Avrupa'nın önde gelen 14 büyük şirketi tarafından mükemmelliğe ulaşma vizyonu ile kurulmuş, üyelik sistemine dayanan ve kâr amacı taşımayan bir 
kuruluştur." Avrupa Kalite Yönetimi Vakfı, 1999 yılında "İş Mükemmelliği Modeli” olan modelin adını "EFQM Mükemmellik Modeli" olarak değiştirmiştir. "EFQM mükemmellik modeli, kuruluşlara öz değerlendirme vasıtasıyla, mükemmelliğe giden yolun hangi noktasında olduklarını gösteren, kuruluşun güçlü ve zayıf taraflarının ve kritik noktalarının belirlenmesinde yol gösteren ve uygun çözümler sunan, pratik; ancak stratejik açıdan önemli bir modeldir." Avrupalı şirketler pratik bir model olduğu için modeli etkili bir araç olarak kullanmaktadırlar. Model temel olarak, çeşitli süreçler aracilığıyla çalışanların yeteneklerini iş sonuçlarına dönüştürebilme imkânına sahiptir (Kuruşçu, 2003: 85-86).

Avrupa kalite ödülünün temel amac1, TKY'nin Avrupa şirketlerinde uygulanarak destek görmesini sağlamaktır. Avrupa kalite ödülünün kurumsallaştırılma nedeni ise Amerika'daki kalite hareketine karşı Avrupa Kalite Yönetimi Vakfı'nın rekabet gücüdür. Stratejik bir hizmet olarak kullanılan bu ödül kurulduğu günden bu yana Avrupalı kuruluşlara küresel rekabet avantajı sağlamaktadır (Emanet, 2007: 72). Kuruluşların rekabette kalite önceliği ve belirli bir düzende ilerleme isteklerinden dolayı model kuruluştan kuruluşa sabit, ortak bir tarzın gelişimini sağlamaktadır. Kalite esasına dayalı bir piyasa yaratan EFQM, Amerika pazarına karşı Avrupalı şirketlerin de rekabet gücünü artırımışır. EFQM; organizasyonların yapısı ne olursa olsun tüm organizasyonlara uygulanabilecek bir modeldir. Kurumdaki çalışanların bilgi ve deneyimlerini aktif bir şekilde paylaşabildikleri ortak bir dil sağlayan model, kaliteyi bir bütün olarak ele almayı başarmıştır.

Bütün kurum ve kuruluşlarda farklı şekillerde uygulanabilecek pratik bir araç olan modelin kullanım amaçları arasında sayılabilecek uygulamalar şunlardır;

- Mükemmelliğe giden yolda nerede bulunduğunun değerlendirilmesi,

- Kuruluşun vizyon ve misyonuna bağlı olarak kuvvetli yönlerin ve iyileştirilecek alanların farkına varılması.

- Kuruluşun; fikirlerini kendi içinde veya dişında etkin bir biçimde yayabilmesini kolaylaştırmak için ortak bir dil ve düşünce tarzının oluşturulması.

- Halihazırdaki ve planlanan teşebbüslerin bütünleştirilmesi, tekrarlanabilecek hataların engellenmesi ve yapılacakların belirlenmesidir (KalDer, 2013: 7).

Türkiye EFOM ürünlerinin ticari kullanım haklarına sahiptir. Bu durumun yaygınlık ve etkinlik kazanması için 1991'de "Türkiye Kalite Derneği'” kurulmuştur. Mükemmellik kültürünü yaşam biçimi haline getirmeye çalışan KalDer misyonu, ülkemzin refah düzeyi ve rekabet gücü açısından ilerlemesine katkı sağlamaktadır. KalDer, "Avrupa Kalite Yönetimi Vakfı'nın Ulusal İş Birliği Ortağı, Amerika Kalite Derneği'nin küresel iş birliği ortağı (ASQ) ve aynı zamanda Orta Doğu Kalite Organizasyonu'nun (MEQA) kurucu üyesidir." KalDer'in temel faaliyetleri arasında "Türkiye Mükemmellik Ödülü, Kalite ve Yönetim alanındaki eğitimleri, Kalite Kongreleri, Kıyaslama çalışmaları, Ulusal Kalite Hareketi ve Türkiye Müşteri Memnuniyeti Endeksi çalışması sayılabilir"” (KalDer, 2013: 1).

Kurumların devamlılıkları, kendilerini nerde gördükleri, çevre ve sektör açısından hangi seviyede bulundukları ve kurumların bu sektörde nasıl bir işleve sahip olduklarını idrak etmeleri gerekmektedir. Bu bilinç ise kurumların çevrelerine karşı geliştirebildikleri rekabet koşullarını etkilemektedir ve bu rekabet koşullarından etkilenebilmektedirler. Böyle kontrol dinamizmleri kurumların yapılarına göre yönetim organizasyonları oluşturmaktadır. Mükemmellik modeli, “herhangi bir şirkette verimliliği en yüksek seviyeye yükseltmek, sıfır hataya olabildiğince yakınlaşmak ve maksimum müşteri memnuniyeti sağlamak açısından benimsenmesi gerekli olan ve işletme içi tam katılımın gerçekleştirildiği bir yönetim yaklaşımıdır" (Efil, 2010: 98).

\subsection{EFQM MÜKEMMELLIKK MODELININ TEMEL KAVRAMLARI}

EFQM Mükemmellik Modeli'ni açıklayan sekiz kavram vardır. Bu kavramlar kapsamlı ve her tür organizasyonla ilgilidir. Organizasyon mükemmellik yolculuğuna başlamak istediğinde, bu kavramları gerçeklik bağlamında ve koşullarına uygunluk kavramında anlamaktadır (Jackson, 1999: 244). EFQM Mükemmellik Modelinin temel kavramları (KalDer, 2002: 24):

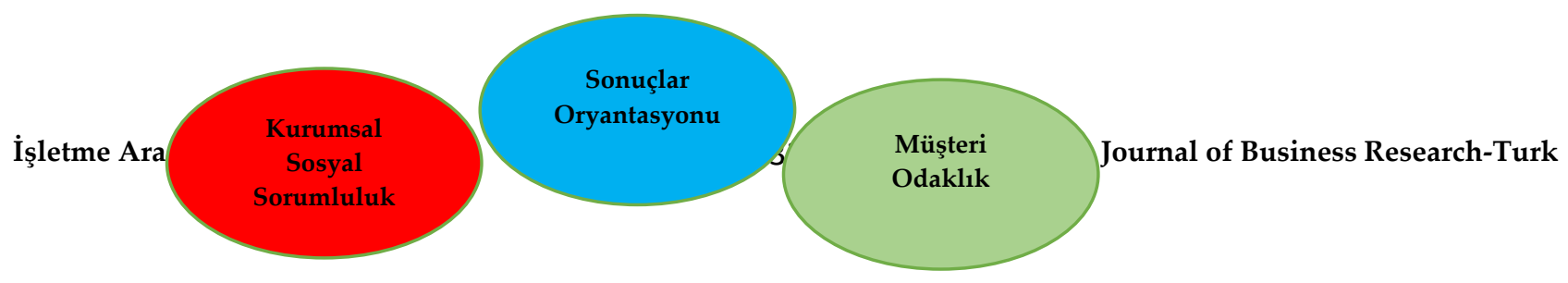




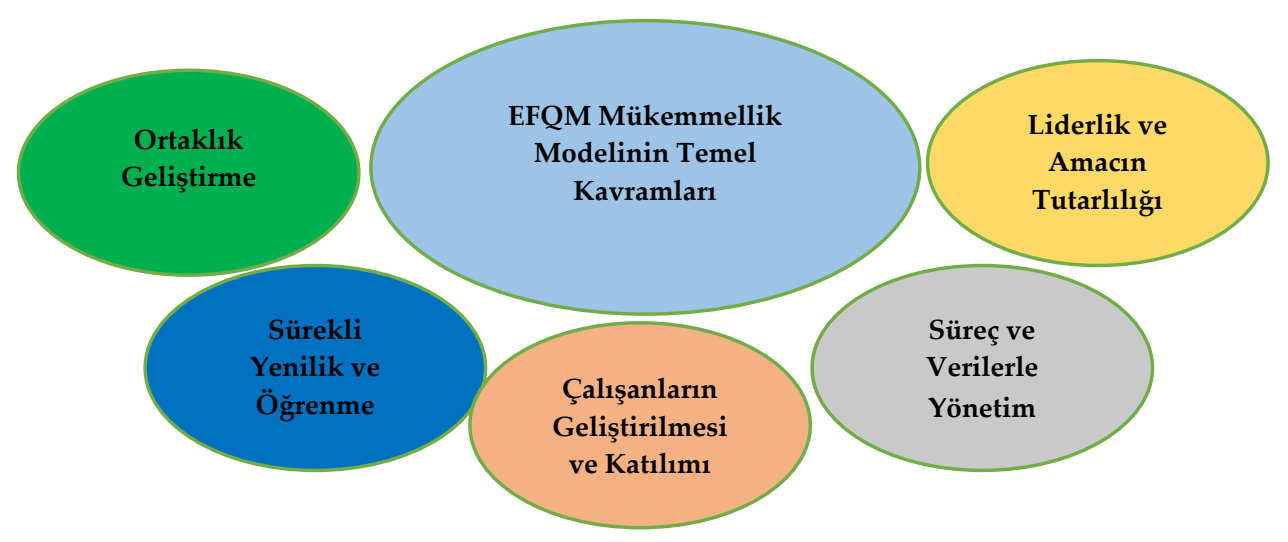

Şekil 1. EFQM Mükemmellik Modelinin Temel Kavramları

\section{ARAŞTIRMANIN METODU}

Araştırma bulgularının genele yayılması ve içerisinden araştırma örnekleminin seçildiği büyük gruba evren denilmektedir. " $\mathrm{N}$ " simgesiyle gösterilir. Evren içerisine örnekleme girme ihtimali bulunan her bir analiz birimine öğe denilmektedir. Öğeler insan, grup, işletmeler, yazılı belgeler hatta bazen sosyal olgular (evlilikler, boşanmalar, tutuklanmalar, davalar vb.) bile olabilmektedir. Örneklem ise, belirli bir evrendeki birimler arasından sistematik bir şekilde seçilen ve evreni temsil ettiği kabul edilen daha küçük kümeler olarak tanımlanmaktadır. Araştırma evreninden örneklem seçim işlemine örnekleme denmektedir (Gürbüz ve Şahin, 2016:127).

Araştırmanın evrenini Karabük Devlet Hastanesi'nde çalışanlar oluşturmaktadır. Duyarlılık, güven düzeyi ve seçilecek örnekteki birim sayısı birbiri ile ilişkili değerlerdir. İstenilen düzeyde duyarlılık ve güvenirliliği sağlayan örnek çapı yığındaki birim sayısına bağlı olarak aşağıdaki formülde verilmiştir. Bu çalışmada aşağıdaki örneklem hesaplama formülünden yararlanılmıştır.

Burada N yığındaki birim sayısını, z istenilen güvenirlilik düzeyi için standart normal dağılımdaki kritik değeri, d duyarlılı̆̆ı, s ise standart sapmayı göstermektedir. Eğer örnekleme çalışması yığındaki oran üzerine ise; orana ilişkin varyans,

$$
s^{2}=p \cdot q \quad(q=1-p)
$$

olduğundan yukarıdaki formül;

$$
n=\frac{N z^{2} p q}{N d^{2}+z^{2} p q}
$$

şeklinde ifade edilir (Yamane, 2001:116).

N: yığınındaki birey sayısı

n: örneklemdeki birey sayısı

z: istenilen güvenirlik düzeyi için standart normal dağılım tablo değeri

d: duyarlılık (araştırma için kabul edilebilir hata payı)

p: yığındaki istenilen özelliği taşıyan bireylerin oranı $(p+q=1)$ 
Yığından seçilecek örneklem sayısı yukarıda gösterilen formül uygulanarak elde edilir. Çalışmanın niteliği göz önüne alınarak, örneklem sayısı, $\% 95$ güvenirlik ve $\% 5$ duyarlılık ile tespit edilmiştir. Bu durumda gerekli örneklem sayısı yaklaşık 158 kişi olduğu tespit edilmiştir. 210 çalışan anketi cevaplamış olup yapılan uygulama sonucunda toplam 201 anket değerlendirmeye alınmıştır.

Yapısal Eşitlik Modellemesi, 1960'lı yılların sonunda gelişmeye başlamış çeşitli araştırma alanlarında kullanılan gizli değişkenler ve ölçüm değişkenleri arasında kurulan hipotezleri test etmede kullanılan istatistiksel bir analiz yöntemidir. Yapısal Eşitlik Modeli'nde aralarında sebep-sonuç ilişkisi olduğu düşünülen değişkenler incelenmektedir. Gizli değişken direkt olarak gözlenemeyen ve kavramsal olarak ortaya atılıp model ile test edilen değişken türüdür. Ölçüm değişkeni ise gözlenen, müşterilere genellikle anket formları ile sorulan ve verileri toplanan değişken türüdür (Aktepe, 2015: 43).

Yapısal Eşitlik Modellemesi gizli ve ölçüm değişkenleri arasındaki neden sonuç ve korelasyon ilişkilerinin birlikte işlendiği modellerin test edilmesi için kullanılan bir istatistiksel analiz yöntemidir. Model ayrıca bağımlılık ilişkilerini tahmin etmek için varyans, kovaryans analizleri, faktör analizi ve çoklu regresyon gibi analizlerin bir arada işlenmesiyle meydana gelmektedir. Pazarlama, psikoloji gibi birçok sosyal bilim dalında belirlenen değişkenler arasındaki ilişkilerin analizinde ve modellerin testinde yapısal eşitlik modellemesinden yararlanılmaktadır (Dursun ve Kocagöz, 2010: 3).

Yapısal Eşitlik Modeli, regresyon analizinde olduğu gibi bir bağımlı ve bağımsız değişken arasındaki bağıntıyı incelemek yerine, birden fazla bağımlı ve bağımsız değişken arasındaki bağıntıyı incelemekte ve belli bir süreç, sistematik ve kapsamda değerlendirme olanağı sağlamaktadır. Karışık modellerin analizinde başarılı olan, birçok analizi tek seferde yapan yapısal eşitlik modellemesi analiz yapılan modeldeki ilişkilere yönelik düzeltmeleri tavsiye etmesi, ölçüm hatalarını göz önünde bulundurması gibi birçok sebepten dolayı araştırmacılar tarafından büyük oranda tercih edilmektedir. Ayrıca, yapısal eşitlik modellemesi yöntemiyle analiz edilen bir modelin diğer bir yönü ise regresyon analizlerinde her bir ilişki için bir regresyon analizine gerek duyulurken, LISREL vb. yazılımlarla ortaya konulan analizlerde, değişkenler arasında belirlenen tüm ilişkiler tek bir analizle ortaya konmakta, ayrıca ek olarak yol analizinde ölçümden kaynaklanan hata miktarı elimine edilmektedir (Dursun ve Kocagöz, 2010: 2).

Her istatistiksel sonuç çıkarım yönteminde olduğu gibi, yapısal eşitlik modelinde de modelin uyum iyiliğinin testi yapılır. Uyum iyiliği için geliştirilen çok sayıda test istatistikleri vardır. Modelin uyum iyiliğinin en önemli ölçütü ki-kare istatistiğidir. Ancak ki-kare istatistiği modeldeki veri ve paremetre sayısına bağlı olarak yüksek değerler alabilmektedir. Bu zayıf yönünden dolayı ki-kare istatistiğinin serbestlik derecesine oranı kritik değer olarak kullanılır. Doğrulayıcı faktör analizinde, $\chi 2 / s d$ 'nin kriter olarak kullanılmasında genel anlamda görüş birliği vardır. Ancak diğer diğer uyum testleri kullanımı konusunda görüşbirliğgi bulunmamaktadır. Bu konudaki tartışmalar İlhan ve Çetin (2014)'den takip edilebilir. Yaygın kullanılan diğer bir uyum iyiliği ölçütü RMSEA değeridir. Analiz edilen modelde, $\chi 2 / s d$ değeri 2 den küçük ise mükemmel uyum iyiliği, 2 ile 5 arasında ise kabul edilebilir uyum iyiliği vardır denir. Yine modelde RMSEA değeri 0,05'den küçük ise mükemmel uyum iyiliği, 0,05 ile 0,10 arasında ise kabul edilebilir uyum iyiliği vardır denir (İlhan ve Çetin, 2014:31, Özdamar, 2016:185, Doğan, 2015:29).

\section{BULGULAR}

Yapılan anket sonuçları yapısal eşitlik analizinde yorumlanarak aşağıdaki bulgular elde edilmiştir. Liderlik kavramı, mükemmelik modellemesi üzerinden A,B,C,D ve E boyutlarına ayrılarak ele alınmıştır. Bu boyutlarda belirtilen sorular aşağıda gösterilmiştir.

A- Kuralları geliştirme ve mükemmellik kültürünün rol modeli olma: Liderler misyon, vizyon, değerler ve etik kurallar geliştirir ve mükemmellik kültürünün rol modelleri olurlar.

B- Kurumun yönetim sisteminin geliştirilmesi ve sürekli olarak iyileştirilmesi: Liderler kurumun yönetim sisteminin geliştirilmesi, uygulanması ve sürekli iyileştirilmesi ile kişisel olarak ilgilenirler

C- Paydaşlarla etkileşime girme: Liderler müşterilerle, ortaklarla ve toplum temsilcileriyle etkileşime girer.

D- Personelin mükemmellik kültürünü geliştirme: Liderler, kurumun personelindeki Mükemmellik kültürünü pekiştirir

E- Örgütsel değişimi tanımlama ve öncülük etme: Liderler örgütsel değişimi tanımlar ve öncülük ederler 
N. Soyhan - N. Soyhan 11/4 (2019) 3323-3336

Tablo 1: Çalışmada kullanılan anket soruları

\begin{tabular}{|c|c|}
\hline a1 & Yönetim, kurum için değer ve hedef belirlemede yer almaktadır \\
\hline a2 & $\begin{array}{l}\text { İşletme kültürünü destekleyen değerler, etik kurallar ve kamusal sorumlulukları geliştirip rol } \\
\text { modelliği yapmaktadır }\end{array}$ \\
\hline a3 & Yönetim çalışanlar için örnek olacak şekilde hareket etmektedir \\
\hline a4 & Bireysel motivasyonu destekleyen örgütsel iklim oluşturmaktadır \\
\hline a5 & Takım çalışmasını destekleyen örgütsel iklim oluşturur. \\
\hline a6 & $\begin{array}{l}\text { Örgütsel misyon, vizyon ve stratejik planı desteklemek üzere tıbbi personel ile etkin ilişkiler } \\
\text { geliştirir }\end{array}$ \\
\hline a7 & Yönetici ulaşılabilir, personelin sorunşlarını dinler ve uygun çözüm alternatifleri sunmaktadır \\
\hline a8 & Kurumda her düzeyde bireysel ve ekip faaliyetlerini hızkı ve uygun şekilde takdir eder \\
\hline b1 & Yönetim, liderlik tarzı ve tekniklerini hastanemizde etkin bir şekilde uygulamaktadır \\
\hline b2 & Etkin kişisel liderlik davranışların gözden geçirip iyileştirmektedir \\
\hline b3 & Yönetim, aktif olarak iyileşleştirme faaliyetlerine katılmaktadır \\
\hline b4 & Yönetim, kurumda olmadıkları zaman vekâlet edebileceklerin bulunmasını temin ediyor mu? \\
\hline b5 & $\begin{array}{l}\text { Liderlik teorisi ve durumsal uygulamaları hastane bünyesinde uyumlaştırmakta ve } \\
\text { uygulamaktadır. }\end{array}$ \\
\hline b6 & $\begin{array}{l}\text { Geliştiirlen ve uygulanan kilit sonuçlar ölçülmesi, gözden geçirilmesi ve iyileştirilmesi sürecini } \\
\text { temin etmektedir. }\end{array}$ \\
\hline b7 & Yönetim çalışanlarla açık ve dürüst iletişimi yaklaşımı uygulamaktadır \\
\hline b8 & $\begin{array}{l}\text { Geliştirilen ve uygulanan kilit sonuçlar ölçülmesi, gözden geçirilmesi ve iyileştirilmesi sürecini } \\
\text { temin ederler }\end{array}$ \\
\hline $\mathrm{c} 1$ & Karar alırken bu kararların içsel ve dışsal etkilerini ve yansımalarını dikkate almaktadır \\
\hline $\mathrm{c} 2$ & Yönetim, yapıcı eleştiriye açıktır \\
\hline c3 & Yasal ve yönetsel standartlara uygun hareket eder ve bunlara uyulmasını sağlamaktadır. \\
\hline c4 & $\begin{array}{l}\text { Sağlık politikası ile ilgili inisiyatiflere özellikle mükemmelliği destekleyen konferans ve } \\
\text { seminerlere katılır ve destekler }\end{array}$ \\
\hline c5 & $\begin{array}{l}\text { Yönetim işbirliğini geliştirmek ve kullanmak amacıyla çıar sahiplerine (ör: doktorlar, personel, } \\
\text { hastalar, halk, devlet vs.) özen göstermektedir }\end{array}$ \\
\hline c6 & $\begin{array}{l}\text { Yönetim, kalite gelişimi için çıkar sahiplerini bilgi kaynağı olarak kabul etmekte ve onlarla } \\
\text { görüşmektedir }\end{array}$ \\
\hline c7 & Yönetim, tedarikçileri uzun dönem ortağı olarak ele almaktadır \\
\hline $\mathrm{c} 8$ & Yönetim, kurumun kamu nazarında pozitif imajını desteklemek için aktif bir çaba sergilemektedir \\
\hline $\mathrm{d} 1$ & Yönetim, karşılıklı güveni destekleyen ve bunun gelişimini sağlayan bir ortam oluşturmaktadır \\
\hline $\mathrm{d} 2$ & Yönetim, süreç yönetimi sistemi geliştirilmesi ve uygulanmasını temin etmektedir \\
\hline $\mathrm{d} 3$ & $\begin{array}{l}\text { Yönetim, örgütsel değer ve kültürlerinin, işletme süreçlerinin ve sistemlerin faaliyetlere etkisi de } \\
\text { dahil örgütsel değerlendirmeleri yapmaktadır }\end{array}$ \\
\hline $\mathrm{d} 4$ & Kurumdaki yüksek potansiyele sahip yetenekleri destekler ve geliştirir. \\
\hline $\mathrm{d} 5$ & Yönetim, hedeflere ulaşma konusunda çalışanları desteklemektedir \\
\hline $\mathrm{d} 6$ & Yönetimi sorumluluk ve gerekli yetkiyi çalışanlara aktarmaktadır \\
\hline
\end{tabular}


N. Soyhan - N. Soyhan 11/4 (2019) 3323-3336

\begin{tabular}{|c|c|}
\hline $\mathrm{d} 7$ & $\begin{array}{l}\text { Örgütsel amaçları çalışanlarla birlikte belirler ve bunların başarımı konusunda kendisini ve } \\
\text { diğerlerini sorumlu tutar }\end{array}$ \\
\hline $\mathrm{d} 8$ & Hekimlerin riski alması ve yeni iş alanları oluşturması konusunda ikna eder \\
\hline d9 & Yönetim çalışanların performansını fark edip ödüllendirmektedir. \\
\hline $\mathrm{d} 10$ & $\begin{array}{l}\text { Çalışanların kurumun başarısına katkıda bulunmaları için yüksek motivasyona sahip olmaları } \\
\text { yönünde, yönetim görev ve prosedürleri yerine getirmektedir }\end{array}$ \\
\hline d11 & Yönetim çalışanları örgütsel gelişim için fikir ve önerilerini sunmaya teşvik etmektedir. \\
\hline $\mathrm{d} 12$ & Çalışanların bilgi, iletişim talepleri ve beklentileri karşılanmakta ve göz önünde tutulmaktadır \\
\hline e1 & $\begin{array}{l}\text { Örgütsel yapıyı değiştierek yetkilendirme,gelişim ve inovasyonu harekete geçirip teşvik } \\
\text { edmektedir }\end{array}$ \\
\hline e2 & Çözüme liderlik eder ve karar almayı teşvik edmektedir \\
\hline e3 & $\begin{array}{l}\text { Kurumun yapısını politika ve stratejileirni destekleyecek şekilde konumnlandırır ve } \\
\text { güncellenmesine yönelik süreçleri geliştirerek uygular }\end{array}$ \\
\hline e4 & Sürekli kurumsal öğrenim ve iyileştirme faaliyetlerini desteklemektedir \\
\hline e5 & Sürekli olarak örgütsel gelişim büyüme ve fırsatlarını araştırır ve değerlendirir. \\
\hline e6 & $\begin{array}{l}\text { Gelecekte ortaya çıabilecek(öngörülen) engelleri aşmak için stratejileri planlar ve bunları } \\
\text { dökümante eder rapor haline getirir. }\end{array}$ \\
\hline e7 & Faaliyetlerin sürdürülebilmesi için ihtiyaç duyulan kaynakları tahmin eder ve önlem alır. \\
\hline e8 & Örgütte değişimi tetikleyen içsel ve dışsal faktörleri doğru algılamaktadır \\
\hline e9 & $\begin{array}{l}\text { Örgüt bünyesinde yapılması gerekli olan değişimeleri tespit edmekte uygulama planları } \\
\text { geliştirmektedir. }\end{array}$ \\
\hline $\mathrm{e} 10$ & Personel v e çıkar sahiplerine değişimi ve gerekliliğini iyi bir şekilde anlatabilmektedir. \\
\hline
\end{tabular}

\section{1. Çalışmanın Modeli}

Yapılan araştırmanın yapısal eşitlik analizi için AMOS programı ile oluşturulmuş modellemesi aşağıdaki tabloda gösterilmiştir. Yapılan araştırmanın yapısal eşitlik analizi için AMOS programı ile oluşturulmuş modellemesi Şekil2'de gösterilmiştir. Modelin uyum iyiliği için $\chi 2 /$ sd kriteri değeri 2,042 ve RMSEA kriteri değeri 0,072 olarak hesaplanmıştır. Bu sonuçlar model için uyum iyiliğinin kabul edilebilir aralıkta olduğunu göstermektedir. 


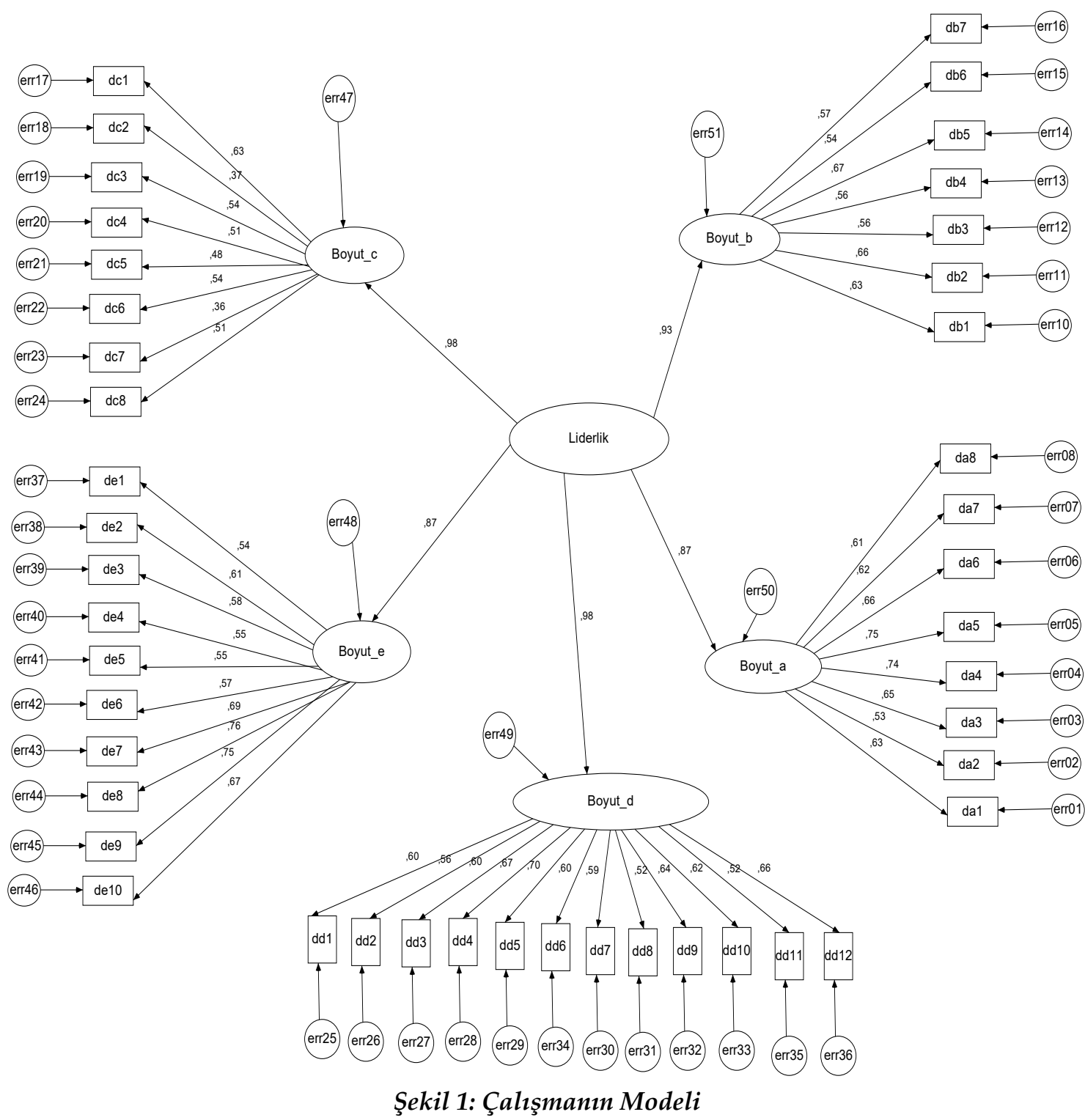

\subsection{Kuralları Geliştirme ve Mükemmellik Kültürünün Rol Modeli Olma Boyutunun Liderliğe Etkisi}

Kuralları geliştirme ve mükemmellik kültürünün rol modeli olma boyutunu liderlik kavramı üzerinden incelediğimizde hemen hemen tüm ifadelerin yakın etkiye sahip olduğu "Takım çalışmasını destekleyen örgütsel iklim oluşturur." sorusunun da boyutun liderlik üzerine etkisini gösteren en güçlü ifade olduğu gözlemlenmektedir.

Tablo 2: Boyutunun Liderliğe Etkisi

\begin{tabular}{|c|c|}
\hline a1 & 0,629 \\
\hline a2 & 0,530 \\
\hline a3 & 0,646 \\
\hline a4 & 0,740 \\
\hline a5 & 0,754 \\
\hline a6 & 0,655 \\
\hline a7 & 0,619 \\
\hline a8 & 0,615 \\
\hline
\end{tabular}




\subsection{Kurumun Yönetim Sisteminin Geliştirilmesi ve Sürekli Olarak İyileştirilmesi Boyutunun Liderliğe Etkisi}

Kurumun yönetim sisteminin geliştirilmesi ve sürekli olarak iyileştirilmesi boyutu ifadelerinin liderlik üzerindeki etkisi aşağıdaki şekilde gösterilmiştir.

Tablo 3: B Boyutunun Liderliğe Etkisi

\begin{tabular}{|c|c|}
\hline $\mathrm{b} 1$ & 0,634 \\
\hline $\mathrm{b} 2$ & 0,659 \\
\hline $\mathrm{b} 3$ & 0,562 \\
\hline $\mathrm{b} 4$ & 0,560 \\
\hline $\mathrm{b} 5$ & 0,674 \\
\hline $\mathrm{b} 6$ & 0,544 \\
\hline $\mathrm{b} 7$ & 0,575 \\
\hline $\mathrm{b} 8$ & 0,570 \\
\hline
\end{tabular}

Kurumun yönetim sisteminin geliştirilmesi ve sürekli olarak iyileştirilmesi boyutu incelendiğinde ise a boyutuna benzer sonuç çıktığını söyleyebiliriz. " Yönetim çalışanlarla açık ve dürüst iletişimi yaklaşımı uygulamaktadır." İfadesinin boyut içinde liderlik üzerinde en büyük etkiye sahip olduğunu görmekteyiz.

\subsection{Paydaşlarla Etkileşime Girme Boyutunun Liderliğe Etkisi}

Paydaşlarla etkileşime girme boyutu sorularının liderlik üzerindeki etkisi aşağıdaki şekilde gösterilmiştir.

Tablo 4: C Boyutunun Liderliğe Etkisi

\begin{tabular}{|c|c|}
\hline $\mathrm{c} 1$ & 0,631 \\
\hline $\mathrm{c} 2$ & 0,37 \\
\hline $\mathrm{c} 3$ & 0,54 \\
\hline $\mathrm{c} 4$ & 0,513 \\
\hline $\mathrm{c} 5$ & 0,481 \\
\hline $\mathrm{c} 6$ & 0,538 \\
\hline $\mathrm{c7}$ & 0,365 \\
\hline $\mathrm{c} 8$ & 0,505 \\
\hline
\end{tabular}

Paydaşlarla etkileşime girme boyutuna bakıldığında " Yönetim, yapıcı eleştiriye açıktır." ve Yönetim, tedarikçileri uzun dönem ortağı olarak ele almaktadır." İfadeleri diğer ifadelere göre daha düşük etkilere sahip olmakla beraber "Karar alırken bu kararların içsel ve dişsal etkilerini ve yansımalarını dikkate almaktadır." İfadesi bu boyutun en yüksek etkiye sahip ifadesidir.

\subsection{Personelin Mükemmellik Kültürünü Geliştirme Boyutunun Liderliğe Etkisi}

Personelin mükemmellik kültürünü geliştirme boyutu sorularının liderlik üzerindeki etkisi aşağıdaki şekilde gösterilmiştir.

Tablo 5: D Boyutunun Liderliğe Etkisi

\begin{tabular}{|c|c|}
\hline $\mathrm{d} 1$ & 0,600 \\
\hline $\mathrm{d} 2$ & 0,563 \\
\hline $\mathrm{d} 3$ & 0,603 \\
\hline $\mathrm{d} 4$ & 0,670 \\
\hline $\mathrm{d} 5$ & 0,701 \\
\hline $\mathrm{d} 6$ & 0,597 \\
\hline $\mathrm{d} 7$ & 0,591 \\
\hline $\mathrm{d} 8$ & 0,521 \\
\hline $\mathrm{d} 9$ & 0,644 \\
\hline $\mathrm{d} 10$ & 0,622 \\
\hline $\mathrm{d} 11$ & 0,523 \\
\hline $\mathrm{d} 12$ & 0,665 \\
\hline
\end{tabular}




\section{N. Soyhan - N. Soyhan 11/4 (2019) 3323-3336}

Personelin mükemmellik kültürünü geliştirme boyutu incelendiğinde ifadelerin etkileri hemen hemen aynı seviyede olduğu görülmüştür. " Yönetim, hedeflere ulaşma konusunda çalışanları desteklemektedir." İfadesi boyutun en yüksek etkiye sahip ifadesidir.

\section{6. Örgütsel Değişimi Tanımlama Ve Öncülük Etme Boyutunun Liderliğe Etkisi}

Örgütsel değişimi tanımlama ve öncülük etme boyutu sorularının liderlik üzerindeki etkisi aşağıdaki şekilde gösterilmiştir.

Tablo 5: E Boyutunun Liderliğe Etkisi

\begin{tabular}{|c|c|}
\hline e1 & 0,538 \\
\hline e2 & 0,608 \\
\hline e3 & 0,583 \\
\hline e4 & 0,552 \\
\hline e5 & 0,547 \\
\hline e6 & 0,572 \\
\hline e7 & 0,695 \\
\hline e8 & 0,759 \\
\hline e9 & 0,754 \\
\hline e10 & 0,666 \\
\hline
\end{tabular}

Örgütsel değişimi tanımlama ve öncülük etme boyutunda da diğer boyutlara benzer olarak birbirine yakın etkilerde bulunan ifadeler yer almaktadır. " Örgütte değişimi tetikleyen içsel ve dışsal faktörleri doğru algılamaktadır." İfadesi boyutun en yüksek etkiye sahip ifadesidir.

\subsection{Tüm Boyutların Liderlik üzerine Etkisi}

Tüm boyutların liderlik üzerindeki etkisi aşağıdaki şekilde gösterilmiştir.

Tablo 6: Tüm Boyutların Liderliğe Etkisi

\begin{tabular}{|c|c|}
\hline A boyutu & 0,985 \\
\hline B boyutu & 0,871 \\
\hline C boyutu & 0,977 \\
\hline D boyutu & 0,872 \\
\hline E boyutu & 0,932 \\
\hline
\end{tabular}

Tüm boyutlar incelendiğinde A boyutunun liderlik üzerinde en etkili boyut olduğu, sonrasında C boyutunun onu takip ettiği görülmektedir. B boyutu tüm boyutla içerisinde en az etkiye sahip olan boyut olmuştur.

\subsection{Boyutlar Arasındaki İlişkinin Analizi}

Boyutların kendi aralarındaki ilişkiler Pearson korelasyon katsayısıyla incelenerek elde edilen bulgular Şekil 8'deki tabloda verilmiştir. Elde edilen bulgulara göre boyutlar arasındaki tüm ikili korelasyon katsayıları istatistiksel olarak anlamlı, pozitif yönlü ve yüksek düzeyde bulunmuştur. En yüksek korelasyon katsayısı boyut c ile boyut $\mathrm{d}$ arasında $(0,994)$, en düşük korelasyon katsayısı boyut a ile boyut e arasında $(0,831)$ hesaplanmıştır. Bu sonuçlara göre liderlik boyutlarından herhangi birisinde gerçekleştirilecek olan alg1 iyileştirmesi diğer boyutlara da pozitif yönlü ve yüksek oranda algı iyileşmesi olarak yansıyacağı şeklinde yorum yapılabilir.

Tablo 7: Liderlik boyutları arasında pearson korelasyon katsayısı bulguları

\begin{tabular}{|l|r|r|r|r|r|}
\hline & \multicolumn{1}{|c|}{ Boyut_a } & \multicolumn{1}{|c|}{ Boyut_b } & \multicolumn{1}{|c|}{ Boyut_c } & \multicolumn{1}{c|}{ Boyut_d } & \multicolumn{1}{c|}{ Boyut_e } \\
\hline Boyut_a & 1 &, $896^{* *}$ &, $923^{* *}$ &, $916^{* *}$ &, $831^{* *}$ \\
\hline Boyut_b &, $896^{* *}$ & 1 &, $975^{* *}$ &, $968^{* *}$ &, $888^{* *}$ \\
\hline Boyut_c &, $923^{* *}$ &, $975^{* *}$ & 1 &, $994^{* *}$ &, $922^{* * *}$ \\
\hline Boyut_d &, $916^{* *}$ &, $968^{* *}$ &, $994^{* *}$ & 1 &, $909^{* *}$ \\
\hline Boyut_e &, $831^{* *}$ &, $888^{* *}$ &, $922^{* *}$ &, $909^{* *}$ & 1 \\
\hline
\end{tabular}

$(* *: p<0,01$ düzeyinde istatistiksel olarak anlamlı ilişkiyi göstermektedir) 


\section{Sonuç}

EFQM (Avrupa Kalite Yönetimi Vakfı) büyüklük, yapı, sektör, ya da gelişmişlik seviyesinden özerk olarak kuruluşların sürdürülebilir mükemmelliğe ulaşmalarını desteklemek adına bir yönetim sistemi kurmaları nedenini öne çıkarmaktadır. Mükemmellik modeli (EFQM) sürekli mükemmelliği yakalamanın pek çok değişik yaklaşımı kullanarak da mümkün olabileceğini kabul eden ve reçete sunmayan bir çerçevedir. EFQM Mükemmellik Modeli, kuruluşların mükemmellik yolunda ilerleyip ilerlemediklerini ölçerek yönetim sistemlerini geliştirmeleri konusunda onlara yardımcı olan pratik bir araç niteliği taşır; kuruluşların kuvvetli yönlerini ve iyileştirmeye açık alanlarını görmelerini sağlayarak onları çözümler üretmeleri konusunda teşvik eder. Araştırmada Karabük Devlet Hastanesinde çalışan 267 kişiye anket yöntemiyle uygulanmıştır. 158 kişinin anketi yapısal eşitlik analizi ile yorumlanmıştır. Analiz sonuçlarında kuralları geliştirme ve mükemmellik kültürünün rol modeli olma boyutunda kurumun yönetim sisteminin geliştirilmesi ve sürekli olarak iyileştirilmesi boyutu incelendiğinde ise a boyutuna benzer sonuç çıktığını söylenebilir. " Yönetim çalışanlarla açık ve dürüst iletişimi yaklaşımı uygulamaktadır." İfadesinin boyut içinde liderlik üzerinde en büyük etkiye sahip olduğunu görülmektedir. Kurumun yönetim sisteminin geliştirilmesi ve sürekli olarak iyileştirilmesi boyutunda kurumun yönetim sisteminin geliştirilmesi ve sürekli olarak iyileştirilmesi boyutu incelendiğinde ise a boyutuna benzer sonuç çıtığını söylenebilir. " Yönetim çalışanlarla açı ve dürüst iletişimi yaklaşımı uygulamaktadır." İfadesinin boyut içinde liderlik üzerinde en büyük etkiye sahip olduğunu görmekteyiz. Paydaşlarla etkileşime girme boyutuna bakıldığında " Yönetim, yapıcı eleştiriye açıtır." ve "Yönetim, tedarikçileri uzun dönem ortağı olarak ele almaktadır." İfadeleri diğer ifadelere göre daha düşük etkilere sahip olmakla beraber "Karar alırken bu kararların içsel ve dışsal etkilerini ve yansımalarını dikkate almaktadır." ifadesi bu boyutun en yüksek etkiye sahip ifadesi olarak belirlenmiştir. Personelin mükemmellik kültürünü geliştirme boyutu incelendiğinde ifadelerin etkileri hemen hemen aynı seviyede olduğu görülmüştür. " Yönetim, hedeflere ulaşma konusunda çalışanları desteklemektedir." İfadesi boyutun en yüksek etkiye sahip ifadesi olarak söylenebilir. Personelin mükemmellik kültürünü geliştirme boyutu incelendiğinde ifadelerin etkileri hemen hemen aynı seviyede olduğu görülmüştür. " Yönetim, hedeflere ulaşma konusunda çalışanları desteklemektedir." İfadesi boyutun en yüksek etkiye sahip ifade olduğu görülmüştür. Örgütsel değişimi tanımlama ve öncülük etme boyutunda da diğer boyutlara benzer olarak birbirine yakın etkilerde bulunan ifadeler yer almaktadır. " Örgütte değişimi tetikleyen içsel ve dışsal faktörleri doğru algılamaktadır." İfadesi boyutun en yüksek etkiye sahip ifade olarak görülmektedir.

\section{Kaynaklar}

Akman, Vedat; Hanoğlu, Merve; Kızıl, Cevdet (2015). Liderlik İle Personel Performansı Arasındaki ilişki Üzerine Bir Şirket İncelemesi. Elektronik Sosyal Bilimler Dergisi, Cilt:14 Sayı:52, 130-145.

Burns, J. M. (1978). Leadership. New York: Harper ve Row Publishers.

Dinçer, Müjde Ker; Bitirim, Selin (2007). Kurum Kültürü Çalışmalarında Hizmetkâr Liderlik Anlayışı ile Değer Yaratmak. İstanbul Üniversitesi iletişim Fakültesi Dergisi, Sayı 28, 61-72.

Dursun Y. ve Kocagöz E., Yapısal Eşitlik Modellemesi ve Regresyon: Karşılaştırmalı Bir Analiz. Erciyes Üniversitesi İktisadi ve İdari Bilimle Fakültesi Dergisi, Ocak-Temmuz, 35, 1-17. 2010.

Drucker, P, F.(2000), Yeni gerçekler. Çeviren: Birtane Karanakçı.7.Baskı, Ankara: Türkiye İş Bankası Kültür Yayınları, Yayın No:327.

Efil, İ. (2010). Toplam Kalite Yönetimi. Bursa: Dora Yayınları.

Emanet, H. (2007). EFQM Mükemmellik Modeli İle Kamu Sektöründe Özdeğerleme Çalışmaları Üzerine Bir Saha Çalışması. Cumhuriyet Üniversitesi İktisadi ve İdari Bilimler Dergisi, 67-95.

Eraslan, L. (2004), “Liderlik Olgusunun Tarihsel Evrimi, Temel Kavramlar ve Yeni Liderlik Paradigmasının Analizi”. Milli Eğitim Dergisi, 162, 109-120.

Evans, J. R. (2008). Quality \& Performance Excellence. Cengage Learning, Canada.

Gürbüz, S., Şahin F. (2016) Sosyal Bilimlerde Araştırma Yöntemleri, Seçkin Yayıncılık. 
N. Soyhan - N. Soyhan 11/4 (2019) 3323-3336

Doğan, İ. (2015) “Farklı Veri Yapısı Ve Örneklem Büyüklüklerinde Yapısal Eşitlik Modellerinin Geçerliği Ve Güvenirliğinin Değerlendirilmesi", Eskişehir Osmangazi Üniversitesi, Sağlık Bilimleri Enstitüsü, Doktora Tezi, 2015

Jackson, S. (1999). "Exploring the Possible Reasons Why the UK Government Commended the EFQM Excellence Model as the Framework for Delivering Governance in the New NHS". International Journal of Health Care Quality Assurance, 12(6): 244-253.

İlhan, M., Çetin, B. (2014) 'LISREL ve AMOS Programları Kullanılarak Gerçekleştirilen Yapısal Eşitlik Modeli (YEM) Analizlerine İlişkin Sonuçların Karşılaştırılması" Eğitimde ve Psikolojide Ölçme ve Değerlendirme Dergisi, Cilt 5, Sayı 2,

KalDer. (2002). Eğitim Kurumları için Toplam Kalite Yönetimi ve Özdeğerlendirme. Türkiye Kalite Derneği (Kalder), İstanbul.

KalDer. (2013). EFQM Mükemmellik Modeli. İstanbul: KalDer Yayınları.

Kuruşçu, M. (2003). Toplam Kalite Yönetimi ve Kalite Ödülleri. İstanbul: Kültür Sanat Yayıncllık.

Medhurst, D., ve Richards, D. (2003). Self-assessing for Excellence. D\&D Excellence Limited, 1-12.

Saavedra, J. (2005). El Modelo EFQM Como Herramienta de Mejora Continua Para el Sistema Cooperativista Vitivinícola de la DO Valencia España. Doctoral Dissertation, Valencia.

Shrivastava, P. ve Nachman, S. A. (1989). "Strategic Leadership Partners" [Stratejik Liderlik Ortakları], Strategic Management Journal Special Issue: Strategic Leaders and Leadership, 10, 51-66.

Özdamar, K. (2016) Ölçek ve Test Geliştirmesinde Yapısal Eşitlik Modellemesi, Nisan kitapevi.

Vries, M. Kets de (2007), Liderliğin Gizemi,Mess Yayınları, İstanbul.

Yamane, T., (2001) Temel Örnekleme Yöntemleri, Literatür Yayınları. 